\title{
Effects of protein intake prior to carbohydrate-restricted endurance exercise: a randomized crossover trial
}

Mads S. Larsen ${ }^{1,2^{*}}$ (D) Lars Holm ${ }^{3}$, Mads V. Svart ${ }^{4,5}$, Astrid J. Hjelholt ${ }^{4}$, Mads B. Bengtsen ${ }^{4}$, Ole L. Dollerup ${ }^{4}$, Line B. Dalgaard ${ }^{1}$, Mikkel H. Vendelbo ${ }^{6,7}$, Gerrit van Hall ${ }^{8,9}$, Niels Møller ${ }^{4,5}$, Ulla R. Mikkelsen ${ }^{2}$ and Mette Hansen ${ }^{1}$

\begin{abstract}
Background: Deliberately training with reduced carbohydrate availability, a paradigm coined training low, has shown to promote adaptations associated with improved aerobic capacity. In this context researchers have proposed that protein may be ingested prior to training as a means to enhance the protein balance during exercise without spoiling the effect of the low carbohydrate availability. Accordingly, this is being practiced by world class athletes. However, the effect of protein intake on muscle protein metabolism during training low has not been studied.

This study aimed to examine if protein intake prior to exercise with reduced carbohydrate stores benefits muscle protein metabolism in exercising and non-exercising muscles.
\end{abstract}

Methods: Nine well-trained subjects completed two trials in random order both of which included a high-intensity interval ergometer bike ride (day 1), a morning (day 2) steady state ride (90 min at 65\% VO 2 peak, 90ss), and a 4-h recovery period. An experimental beverage was consumed before $90 \mathrm{ss}$ and contained either $0.5 \mathrm{~g}$ whey protein hydrolysate [WPH]/ kg lean body mass or flavored water [PLA]. A stable isotope infusion (L-[ring- $\left.{ }^{13} \mathrm{C}_{6}\right]-$ phenylalanine) combined with arterial-venous blood sampling, and plasma flow rate measurements were used to determine forearm protein turnover. Myofibrillar protein synthesis was determined from stable isotope incorporation into the vastus lateralis.

Results: Forearm protein net balance was not different from zero during 90ss exercise ( $\mathrm{nmol} / 100 \mathrm{ml} / \mathrm{min}$, PLA: $0.5 \pm 2.6 ; \mathrm{WPH}: 1.8, \pm 3.3)$ but negative during the $4 \mathrm{~h}$ recovery $(\mathrm{nmol} / 100 \mathrm{ml} / \mathrm{min}, \mathrm{PLA}:-9.7 \pm 4.6 ; \mathrm{WPH}:-8.7 \pm 6.5)$; no interaction $(P=0.5)$ or main effect of beverage $(P=0.11)$ was observed. Vastus lateralis myofibrillar protein synthesis rates were increased during 90ss exercise $(+0.02 \pm 0.02 \% / h)$ and recovery $(+0.02 \pm 0.02 \% / h)$; no interaction ( $P=0.3$ ) or main effect of beverage $(P=0.3)$ was observed.

Conclusion: We conclude that protein ingestion prior to endurance exercise in the energy- and carbohydraterestricted state does not increase myofibrillar protein synthesis or improve net protein balance in the exercising and non-exercising muscles, respectively, during and in the hours after exercise compared to ingestion of a non-caloric control.

Trial registration: clinicaltrials.gov, NCT01320449. Registered 10 May 2017 - Retrospectively registered, https://clinicaltrials.gov/ct2/show/NCT03147001

Keywords: Carbohydrate restriction, Dietary protein, Endurance training, Protein metabolism

\footnotetext{
* Correspondence: msl@ph.au.dk

${ }^{1}$ Department of Public Health, Aarhus University, Dalgas Ave. 4, 8000 Aarhus

C, Denmark

${ }^{2}$ Arla Foods Ingredients Group P/S, Viby J 8260, Denmark

Full list of author information is available at the end of the article
}

(c) The Author(s). 2020 Open Access This article is distributed under the terms of the Creative Commons Attribution 4.0 International License (http://creativecommons.org/licenses/by/4.0/), which permits unrestricted use, distribution, and reproduction in any medium, provided you give appropriate credit to the original author(s) and the source, provide a link to the Creative Commons license, and indicate if changes were made. The Creative Commons Public Domain Dedication waiver (http://creativecommons.org/publicdomain/zero/1.0/) applies to the data made available in this article, unless otherwise stated. 


\section{Introduction}

During the past decade, 'periodization' has been a hot topic in sports nutrition $[1,2]$. The term 'periodized nutrition' refers to strategic manipulation of nutrient availability during training to promote specific adaptations. Among the various strategies, undertaking training with low carbohydrate availability has received much attention by researchers [2-4]. This practice is popularly referred to as training low. Several studies have shown that commencing endurance-type exercise with low endogenous and exogenous carbohydrate availability 1) augments the mobilization of lipids for oxidation and 2) enhances activation and gene transcription encoding key proteins underpinning adaptations associated with a phenotype of improved endurance capacity [5-10]. Among these proteins, AMP-activated kinase (AMPK) and peroxisome proliferator-activated receptor gamma coactivator (PGC)$1 \alpha$ are reputed to play particularly important roles. AMPK acts as a myocellular fuel gauge promoting fatty acid oxidation, while PGC- $1 \alpha$ is considered a master regulator of mitochondrial biogenesis [3]. Congruently, training low is employed by athletes to achieve greater aerobic and fat oxidation capacity [11-13].

Nevertheless, training low comes with a caveat: Typically, amino acids contribute $\sim 5 \%$ of the energy cost during endurance exercise [14]. However, commencing training with low carbohydrate availability may double this contribution, seemingly brought about by accelerating muscle protein breakdown [15-17]. Indeed, low endogenous carbohydrate availability augments leucine oxidation [16] and amino acid release from the working muscle $[16,17]$ and attenuates protein synthesis during exercise [16]. Thus, repetitive practice over an extended period has raised concerns among scientists [11, 18, 19], as it may affect skeletal muscle mass negatively, and possibly compromise athletic performance. Accordingly, a recent study estimated that commencing a $10-\mathrm{km}$ run with reduced carbohydrate availability increases daily protein requirement by $0.12 \mathrm{~g} / \mathrm{kg}$.

As a means to ameliorate the augmented muscle protein breakdown, a few studies have examined the effect of protein feeding before and during training low [20, 21]. These studies have shown that protein ingestion before training in a glycogen-depleted state does not seem to compromise lipolysis and fat oxidation compared to non-caloric placebo treatment [20, 21]. Furthermore, Taylor et al. demonstrated that protein intake before glycogen-depleted exercise did not influence acute AMPK phosphorylation and PGC- $1 \alpha$ mRNA transcription. The authors also suggest that the protein provision before and during the glycogen-depleted training bout appeared to induce greater dephosphorylation (i.e. activation) of the eukaryote elongation factor 2 (eEF2) compared to the placebo trial [20]. Because of its role as a molecular regulator of elongation, the authors inferred that protein ingestion during training low reduced suppression of muscle protein synthesis during exercise [20]. As acknowledged by the authors, a critical limitation to their study is the lack of direct assessment of muscle protein turnover.

Regardless of the limited scientific evidence, world-class endurance athletes evidently already practice protein ingestion before and/or during training low sessions $[12,13]$.

Intrigued by the results by Taylor et al. [20] and the reputed practice of world class athletes, we aimed to conduct a proof-of-principle trial to determine how a protein bolus ingested prior to commencing endurance training in a carbohydrate/energy-restricted condition affects skeletal muscle protein metabolism. We examined muscle protein synthesis in the highly active muscle vastus lateralis and protein kinetics (i.e., net balance, synthesis and breakdown) in the forearm to represent non-exercising muscle tissue. The reason for this choice was that whole-body protein kinetics may not reflect that of the skeletal muscle tissue.

We hypothesized that protein ingestion prior to training low would stimulate muscle protein synthesis in the exercising muscles and would improve protein net balance in non-exercising muscle. Additionally, we examined cell signaling and gene expression associated with myofibrillar and mitochondrial biogenesis to assess how these parameters were affected by protein ingestion prior to training low.

\section{Methods}

\section{Subjects}

Twelve competitive male triathletes or cyclists were included in the study after being deemed healthy and fit for participation. The inclusion criteria required subjects to be healthy (no metabolic abnormalities), non-smokers, 18-50 years old with a relative $\dot{\mathrm{VO}}_{2 \text { peak }}$ above $55 \mathrm{ml} \mathrm{O} / \mathrm{kg} / \mathrm{min}$, and a history of five or more training sessions per week for 6 months prior to inclusion. All participants were given oral and written information and gave their written consent to participate. The study was approved by the local ethical committee of the Central Denmark Region (M-20110035) and was conducted in accordance with the Declaration of Helsinki. The study was registered with clinicaltrials.gov (NCT01320449).

\section{Pretesting}

Prior to the experiment, a routine blood sample was collected to determine the subject's general metabolic health. The blood samples were collected in the fasted state and analyzed for levels of low density lipoprotein, high density lipoprotein, triglycerides, leucocytes, aminotransferase, aspartate aminotransferase, alkaline phosphatase, albumin, testosterone, thyroid stimulating hormones, triiodothyronine, creatine kinase, c-reactive protein and hemoglobin to 
get an indication of any undiagnosed conditions that the participant might unknowingly have suffered from.

Body composition was determined using dual-energy x-ray absorptiometry (DXA; GE Lunar DXA scan, GE Healthcare, USA).

Peak power output (PPO) and peak oxygen consumption $\left(\dot{\mathrm{V}}_{2 \text { peak }}\right)$ were determined independently of the experimental trials and DXA scan, using an incremental test-to-exhaustion on an electronically braked bicycle ergometer (SRM, Julich, Germany) as described previously [22]. $\dot{\mathrm{V}} \mathrm{O}_{2 \text { peak }}$ was defined as the highest oxygen uptake attained during any $30 \mathrm{~s}$ of the test. Respiration was analyzed using an Oxigraf O2CPX (Oxigraf O2CPX, Model Part Number 07-0464, Oxigraf Inc) with Innocor 8.00 software (Innovision ApS, Odense, Denmark). PPO was calculated from the highest completed stage of exercise intensity plus the fraction of time spent in the final uncompleted stage [22]. The individual PPO was used to determine the prescribed intensities during the experimental trials.

\section{Study design}

The protocol is visualized in Fig. 1. In a single-blinded counterbalanced crossover trial, subjects were studied on two occasions (Visit 1 and Visit 2) separated by a minimum of 14 days. The contents of the experimental beverage (whey protein hydrolysate [WPH] or placebo [PLA]) differed; otherwise, the experiments were conducted in a similar manner. Each experimental period covered 2 days and consisted of two exercise sessions performed on an ergometer bike, similar to the protocol described by Lane et al. [7]: the first high-intensity interval training (HIIT) session was performed in the evening of Day 1. The second session, a 90 min steady state (90ss) cycling bout, was performed at $08.00 \mathrm{~h}$ on the following morning (Day 2). All foods consumed on Day 1 were standardized and matched between the two visits. Experimental beverages were ingested immediately prior to 90ss. Ingestion of food and beverages other than water and the experimental beverage was not allowed from arrival at the laboratory until completion of Day 2. Throughout Day 2, fractional protein synthesis rates
(FSR) and muscle protein turnover were determined using stable isotope tracer techniques.

\section{Experimental days}

At both visits, the subjects reported to the laboratory at $1800 \mathrm{~h}$ on Day 1. After voiding their bladder, they commenced the HIIT session. Afterwards a catheter was placed in an antecubital vein. A background blood sample was collected and the catheter was kept patent by continuous infusion of $9 \%$ saline until $0330 \mathrm{~h}(0530 \mathrm{~h}$ at the second visit), when a primed $(6.0 \mu \mathrm{mol} / \mathrm{kg}$ lean body mass [LBM]) continuous $(6.0 \mu \mathrm{mol} / \mathrm{kg} \mathrm{LBM} / \mathrm{h})$ infusion of L- $\left[\right.$ ring $\left.-{ }^{13} \mathrm{C}_{6}\right]$-phenylalanine (Cambridge Isotopes, Andover, MA, USA) was initiated and maintained until the end of Day $2(1330 \mathrm{~h})$. Tracer solutions were sterilely prepared and tested free of bacteria and pyrogens before use. In the morning of Day 2, a catheter was placed contralaterally to the tracer infusion in an antecubital vein, in a retrograde direction, for deep venous sampling. Another catheter was placed in a dorsal hand vein. The hand was heated to $\sim 55^{\circ} \mathrm{C}$ for sampling of arterialized blood. Venous occlusion plethysmography was used to determine forearm blood flow.

Immediately before commencing 90ss, a baseline muscle biopsy and blood samples were obtained, and the experimental beverage was consumed. After completion of 90ss, the subjects were kept in a supine position for the rest of the experiment. A muscle biopsy was obtained immediately, and at 1 and $4 \mathrm{~h}$ of after termination of the 90ss. Urine was collected in two intervals. Batch 1: From the initiation of HIIT to the commencement of 90ss. Batch 2: From the commencement of 90ss to the end of the study period.

\section{HIIT}

After a self-chosen 10-min warm up, the HIIT session was performed on an ergometer bike (LC4, Monark AB, Vangsbro Sweden). The HIIT consisted of ten 5-min bouts at $\sim 82.5 \%$ of individual PPO with $90 \mathrm{~s}$ of active recovery between the intervals. This protocol is a modified version of one described by Stepto et al., which showed a $\sim 50 \%$ reduction in muscle glycogen levels $[7,23]$.

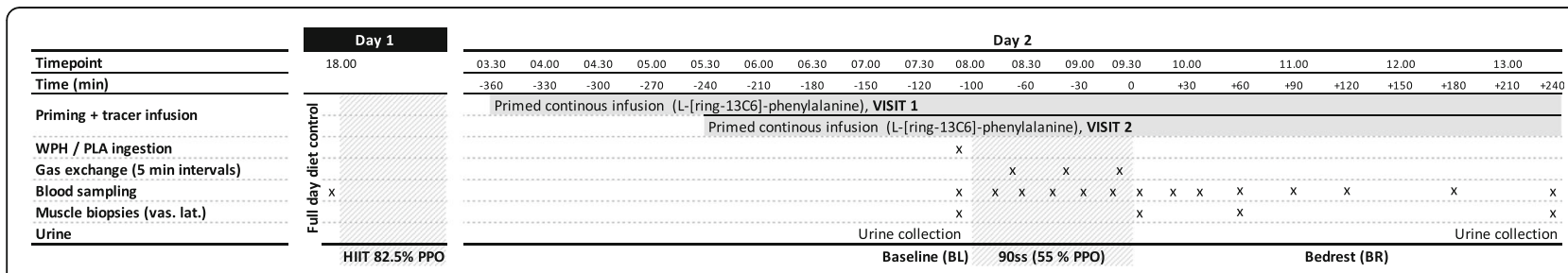

Fig. 1 Overview of study design. On day 1, all meals were provided. At 1900 subjects commenced $10 \times 5$ min intervals at $82.5 \%$ (HIIT) of individual peak power output (PPO) on a customized ergometer bike. L-[ring $-{ }^{13} \mathrm{C}_{6}$-phenylalanine] was initiated during the night. Upon awakening (day 2), blood, muscle and urine samples were collected before commencement of a 90 min steady state ride (55\% PPO). Subsequently subjects rested in a supine position for $4 \mathrm{~h}$. Samples were collected as indicated 
90ss

The work rate was fixed at 55\% of PPO. The bicycle ergometer was modified by addition of customized aerobars with an attached table for hand placement (subjects did not grip the handle bars). The subjects were instructed to remain positioned in the aerobars throughout the exercise bout to minimize muscle activity in the forearms while cycling. $\mathrm{VO}_{2}$ was measured during 5-min intervals every $30 \mathrm{~min}$ of exercise. Ratings of perceived exertion were recorded prior to $\mathrm{VO}_{2}$ measurements. Heart rate was measured continuously throughout 90ss. The work performed during the HIIT and 90ss sessions at Visit 1 was replicated at Visit 2.

\section{Diet and exercise control}

On Day 1, a standardized portion-controlled diet containing (per kg body weight) $6.8 \mathrm{~g}$ carbohydrate, $1.8 \mathrm{~g}$ protein, and $1.7 \mathrm{~g}$ fat was provided for all participants. No exercise, alcohol, caffeinated drinks, or medical drugs were allowed in the $24 \mathrm{~h}$ prior to HIIT. Water was allowed ad libitum at all times during the experimental periods.

\section{Experimental beverages}

were provided immediately before starting the 90ss session and contained either $0.5 \mathrm{~g} / \mathrm{kg}$ LBM WPH (Lacprodan $^{\odot}$ HYDRO.365, Arla Foods Ingredients Group P/S, Viby J, DK) with $10 \% \mathrm{~L}-\left[\right.$ ring- $\left.{ }^{13} \mathrm{C}_{6}\right]$-phenylalanine enrichment (Table 1) or a non-caloric placebo matched for flavor. The amino acid content of the protein beverage is appended (see Additional file 1).

\section{Blood sampling and analysis}

All blood samples were collected into coated vacuum blood collection tubes. Plasma amino acid concentrations and enrichments were determined as described previously [24]. Concentrations of insulin, cortisol, serum glucose, and plasma-free fatty acids (FFA) were quantified as described previously [25, 26]. Hemoglobin (HemoCue Hb 201 $1^{+}$Ängelholm, Sweden) and 3hydroxybuterate (FreeStyle Precision; Abbott Diabetes Care) were measured immediately after sampling. Analyses of plasma and urinary urea and plasma ammonium were performed using absorption photometry (Cobas 6000, Roche, Basel, CH and Chemistry XPT System, Simens Healthcare A/S, Ballerup, DK).

Table 1 Protein beverage content / $100 \mathrm{~g}$

\begin{tabular}{ll}
\hline Water & $85.52 \mathrm{~g}$ \\
Whey protein & $10.00 \mathrm{~g}$ \\
Carbohydrate & $1.33 \mathrm{~g}$ \\
Fat & $0.03 \mathrm{~g}$ \\
Energy & $45.6 \mathrm{kcal}$ \\
\hline
\end{tabular}

All subjects ingested a drink with a protein content equivalent to $0.5 \mathrm{~g} / \mathrm{kg} \mathrm{LBM}$

\section{Muscle biopsies sampling and analyses}

The muscle biopsies $(\sim 250 \mathrm{mg})$ were obtained from the vastus lateralis muscle under local anesthesia $(10 \mathrm{ml}$ Xylocain ${ }^{\odot} 10 \mathrm{mg} / \mathrm{ml}$, AstraZeneca, Sweden) using a 5 mm Bergström needle with manual suction. At each visit, all samples were obtained from the same randomly chosen leg (dominant or non-dominant) through separate incisions. After removing visible blood, fat, and connective tissue, the samples were snap frozen and stored at $-80^{\circ} \mathrm{C}$ until further analysis.

\section{Stable isotope analysis}

For practical reasons, a single biopsy approach was used to assess basal muscle protein FSR at Visit 1 [24, 27, 28]. This value represents basal FSR for both treatments in the statistical analysis. Myofibrillar and mitochondrial proteins were isolated as described previously [29]. Briefly, each muscle sample ( $\sim 25 \mathrm{mg}$ wet weight) was homogenized in $1 \mathrm{ml}$ homogenization buffer $(0.02 \mathrm{M}$ Tris [pH 7.4], $0.15 \mathrm{M} \mathrm{NaCl}$, $2 \mathrm{mM}$ EDTA, $0.5 \%$, TritonX-100 and $0.25 \mathrm{M}$ sucrose) and spun at $800 \mathrm{~g}$ at $5{ }^{\circ} \mathrm{C}$. This procedure was repeated. The resulting supernatants were combined and spun at $10,000 \mathrm{~g}$ $\left(5^{\circ} \mathrm{C}\right)$, washed, and spun in $1 \mathrm{ml} 70 \%$ ethanol $\left(1600 \mathrm{~g}, 5^{\circ} \mathrm{C}\right)$ to pellet the mitochondrial proteins. The original pellet containing myofibrillar and connective tissue proteins was vortexed, left overnight $\left(5^{\circ} \mathrm{C}\right)$ in a $\mathrm{KCl}$ buffer $(0.7 \mathrm{M} \mathrm{KCl}, 0.1 \mathrm{M}$ pyrophosphate) and then spun at $1600 \mathrm{~g}\left(20 \mathrm{~min}, 5^{\circ} \mathrm{C}\right)$. The supernatant was discarded and 99\% ethanol was added and left for $2 \mathrm{~h}$. This procedure was repeated. The resulting myofibrillar protein pellet was hydrolyzed at $110^{\circ} \mathrm{C}$ in $6 \mathrm{M} \mathrm{HCl}$ overnight. Both the mitochondrial and myofibrillar amino acids were purified over prepared resin columns (AG $50 \mathrm{~W}$ X8 resin; Bio-Rad Laboratories, Hercules, CA), eluted with 4 $\mathrm{M} \mathrm{NH}_{4} \mathrm{OH}$, and evaporated under a stream of nitrogen before being derivatized as the $\mathrm{N}$-acetyl-propyl derivative as described elsewhere [30]. Unfortunately, several samples from the mitochondrial fraction resulted in signals too low to detect on the GC/C/IRMS. Therefore, we were unable determine the FSRs for mitochondrial protein.

\section{Calculations}

Calculations of forearm phenylalanine kinetics and muscle protein FSRs were performed as described by Smith et al. [31] and Holm et al. [24], respectively. Calculations are appended (see Additional file 2).

\section{Gene expression}

Approximately $20 \mathrm{mg}$ of muscle tissue was homogenized using a Precellys 24 Tissue Homogenizer (Bertin Instruments, Rockville, MD, USA). Total RNA was isolated using an RNA KIT (Qiagen, \#217004) according to the manufacturer's instructions. Concentrations and purity were confirmed by spectroscopy. All reagents and equipment used were from Applied Biosystems ${ }^{\mathrm{TM}}$ (Foster City, 
Ca, USA). Five hundred nanograms of RNA was converted to cDNA using a High-Capacity cDNA Reverse Transcription Kit, and real time PCR was performed with Fast Advanced Mastermix using a StepOnePlus. Genes (targets IDs) were: CPT1B (HS03046298 s1), COX4I1 (HS00971639 m1), PPARGC1 (HS00173304 $\mathrm{m} 1$ ), TFAM (HS01082775 m1), RPLPO (HS99999902 $\mathrm{m} 1)$ and GAPDH (HS99999905 m1). Data were converted to fold changes from PRE using the Delta Delta Ct method [32] with RPLP0 as the internal control. Ct values obtained for RPLPO were not affected by treatment or time.

\section{Western blots}

Approximately $30 \mathrm{mg}$ of muscle tissue was used to determine protein concentrations via Bradford assays (Bio-Rad, Ca, USA). Target proteins were resolved by $4-15 \%$ sodium dodecyl sulfate-polyacrylamide gel electrophoresis (Criterion TGX gradient 4-15\%, Bio-Rad) with three molecular markers (Precision Plus All Blue, Bio-Rad) and an internal control before being electroblotted to polyvinylidene difluoride membranes (Bio-Rad, CA, USA). The membranes were blocked in I-block ${ }^{\text {tm }}$ Protein-based Blocking Reagent (Applied Biosystems ${ }^{\mathrm{Tn}}$, Bedford, MA, USA) and incubated overnight in primary antibodies followed by TBS-T wash and incubation $(1 \mathrm{~h})$ with secondary antibodies. Primary antibodies (cat. no.): p-mTORser2448 (2971), p-p38MAPKthr180/tyr182 (4511), p-p70S6Kthr389 (9205), p-eIF4Eser209 (9741) and p-p53ser15 (9284), all from Cell Signaling Technology (Danvers, MA, USA).

Horseradish peroxidase-conjugated secondary antibodies: Goat anti-rabbit IgG H\&L (ab6721; Abcam, Cambridge, UK) and Anti-mouse IgG (7076; Cell Signaling Technology (Danvers, MA, USA).

Proteins were visualized using a chemiluminescence detection system (Thermo Scientific, IL, US) and quantified using a Bio spectrum 500 Imaging System (UVP, Cambridge, UK). All Blue Standards (Bio-Rad, CA, USA) were used as molecular weight markers.

\section{Statistical analysis}

An a priori sample size of ten subjects was established based on previous tracer kinetics data from trials similar to ours $[33,34]$. For each treatment (PLA or WPH), time-weighted arithmetic means were calculated for each time period (BL, 90ss and BR) to determine a conjoined and clinically meaningful response for plasma metabolites, hormones and tracer kinetic data. Data on muscle signaling were analyzed and expressed as relative fold change from baseline corresponding to the biopsy obtained immediately before commencing 90ss at each visit. For gene expression, delta CT values were analyzed statistically but expressed as relative fold changes from baseline. Statistical analyses were conducted using a repeated-measures mixed effects model. Treatment, time period (BL, 90ss and BR), and order-of-treatment were included as independent variables. Subject and visit (1 or 2 ) were included in the random part of the model to account for any carry-over effect and random intercepts for the subjects, respectively. This was followed by a joint test of two-way interactions. Significance was set at an $\alpha$-level of $<0.05$. If $F$-ratios were significant, Bonferroni post hoc tests were applied to locate differences. Normality and heteroskedasticity of all data were checked by visually inspecting QQ-plots and plots of residuals versus the fitted values. No obvious deviations of normality were detected. Data that were not homoscedastic (3-hydroxybutyrate, plasma ammonia and amino acid concentrations) were log-transformed for the statistical analyses but not presented as such. Treatment differences in urinary nitrogen excretion and volume of voiding were analyzed using paired t-tests. Values are presented as means \pm standard deviation (SD). All statistical analyses were performed using STATA version 14.2 (StataCorp LP, Collage Station, TX, USA).

\section{Results \\ Study participants}

Of the 12 subjects included in the study, two failed to attend the experimental visits; one due to injury unrelated to the study and one due to scheduling difficulties. One subject did not attend the second trial for personal reasons and was therefore excluded from all analyses. Subject characteristics are shown in Table 2.

\section{HIIT and 90ss}

The mean PPO attained during pretesting was $364 \pm$ 24 watts. The average power output across intervals was $281 \pm 21$ watts. On average, participants dropped $\sim 4.6 \%$ between interval one and ten (95\% CI: -6.7 , $-2.4 ; P<0.001)$. Concomitantly, the rating of perceived exertion rose from $\sim 14$ to $\sim 18$ on the Borg scale $(P<0.001)$. The 90 ss sessions were performed at an average power of $55.6 \pm 2.6 \%$ (PLA) and $54.9 \pm$ $2.9 \%(\mathrm{WPH})$ of PPO. During both trials, the mean respiratory exchange ratio dropped from 0.87 to 0.84 throughout the 90ss session $(P<0.001)$.

Table 2 Subject characteristics $(n=9)$

\begin{tabular}{|c|c|}
\hline Age (years) & $28.6 \pm 9.0$ \\
\hline Body mass (kg) & $73.1 \pm 4.5$ \\
\hline DXA body mass (kg) & $73.7 \pm 4.3$ \\
\hline Lean body mass (kg) & $60.1 \pm 4.2$ \\
\hline $\mathrm{VO}_{2}$ peak $\left(\mathrm{ml} \mathrm{O}_{2} \cdot \mathrm{kg}^{-1} \cdot \mathrm{min}^{-1}\right)$ & $60.0 \pm 2.6$ \\
\hline Peak power output (watt) & $364 \pm 24$ \\
\hline
\end{tabular}

Data are mean \pm SD 


\section{Blood profile}

All blood profiles are illustrated in Fig. 2. Serum insulin (Fig. 2a) was $12.5 \mathrm{pmol} / \mathrm{L}$ higher in WPH than in PLA during 90ss $(P=0.02 ; 95 \% \mathrm{CI}: 0.9,24.1)$, as insulin levels in PLA dropped $12.3 \mathrm{pmol} / \mathrm{L}$ from BL levels $(P=0.03$; 95\% CI: $-23.9,-0.7)$. Both treatments showed lower insulin levels during $\mathrm{BR}$ than at $\mathrm{BL}(P<0.05 ; 95 \% \mathrm{CI}:-10.1,13.1)$. Plasma cortisol increased during 90ss for both treatments and returned to $\mathrm{BL}$ levels during $\mathrm{BR}$. No time-treatment interaction was observed $(P=0.34)$; yet, statistical analysis showed higher plasma cortisol throughout PLA compared with WPH (+36.1 $\mu \mathrm{g} / \mathrm{L} ; P<0.01$; 95\% CI: 62.4, 9.8; Fig. 2b).
Blood glucose was reduced throughout Day 2 in both WPH and PLA (Fig. 2c; $P<0.001$ ). Though not statistically significant, there tended to be an interaction with WPH showing higher glucose levels than PLA $(P=0.097)$. FFA concentrations in PLA were increased during 90ss (0.92 \pm $0.22 \mathrm{mmol} / \mathrm{L} ; P=0.03$; 95\% CI: 0.02, 0.58; Fig. 2d) compared with $\mathrm{BL}(0.62 \pm 0.20 \mathrm{mmol} / \mathrm{L})$ and further during $\mathrm{BR}$ $(1.44 \pm 0.10 \mathrm{mmol} / \mathrm{L} ; P<0.001)$. In $\mathrm{WPH}$, the FFA levels were unchanged from $\mathrm{BL}$ during $90 \mathrm{ss}(\mathrm{mmol} / \mathrm{L}: 0.59 \pm 0.21$ vs $0.73 \pm 0.29 ; P=1.0 ; 95 \% \mathrm{CI}:-0.14,0.43$ ), but rose during BR $(1.04 \pm 0.30 \mathrm{mmol} / \mathrm{L} ; \quad P<0.001 ; 95 \% \mathrm{CI}:-0.17,0.73)$. Plasma 3-hydroxybutyrate concentrations were unchanged
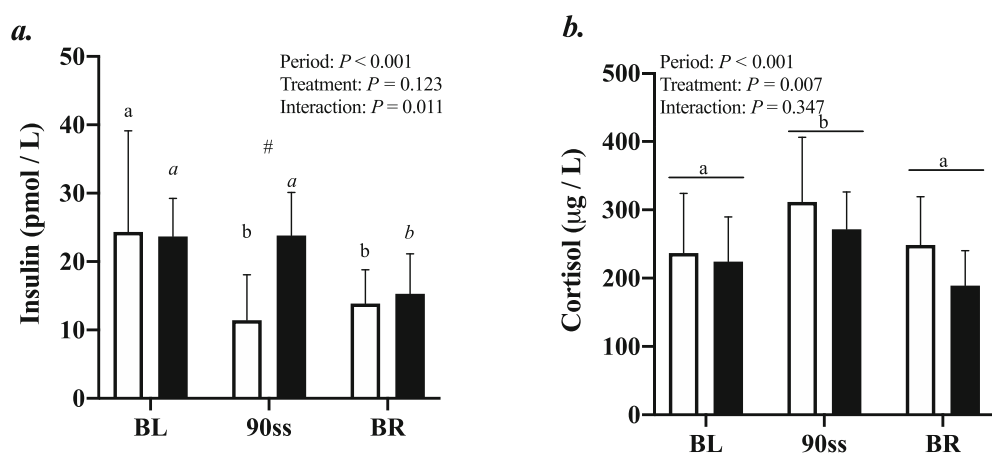

$c$.

d.
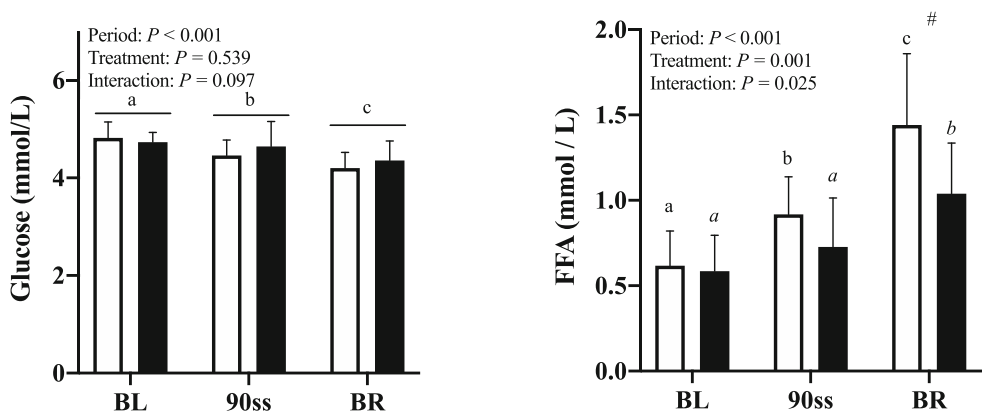

e.

$f$.
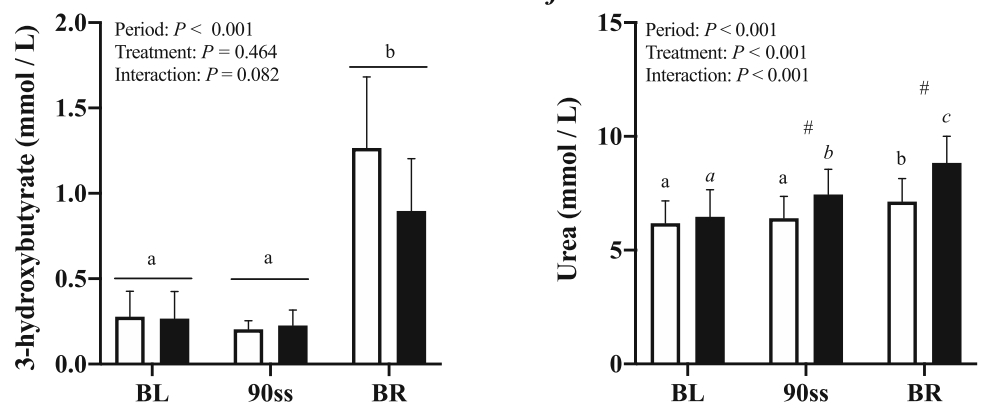

WPH

Fig. 2 Blood parameters. Change in hormone and metabolite levels during BL, 90ss and BR. Insulin (a), cortisol (b), glucose (c), free fatty acids (FFA) (d), 3-hydroxybutyrate $(\mathbf{e})$, urea (f). Data are shown as means \pm SD $(n=9) ; P<0.05$. Means within each trial with different subscripts are significantly different from each other; WPH subscripts are in cursive. \# Significant difference between PLA and WPH at each respective timepoint 

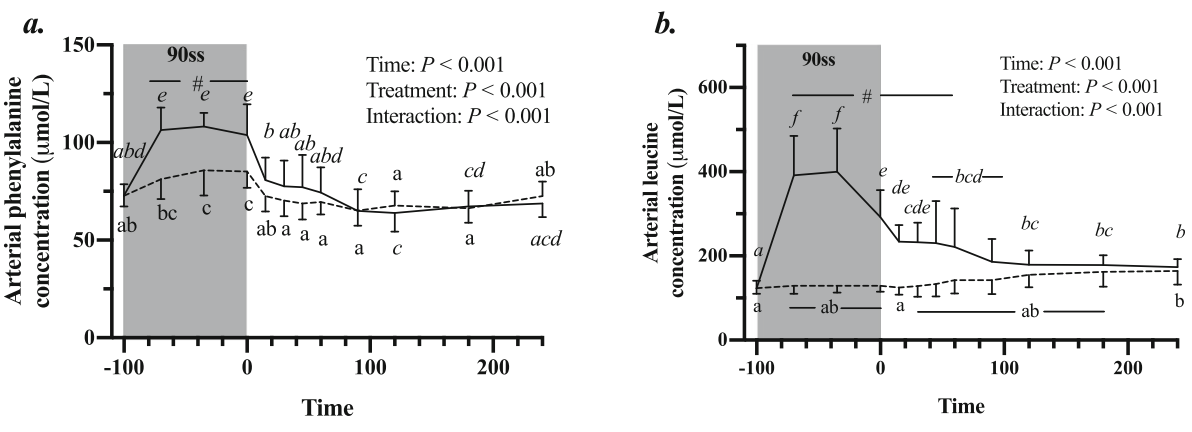

----. PLA

- WPH

Fig. 3 Arterial concentrations of phenylalanine (a) and leucine (b) at baseline (BL), during 90 steady state exercise (90ss) and during bed rest recovery (BR) with PLA or WPH ingestion. Values are means \pm SD $(n=9) ; P<0.05$. Means within each trial with different subscripts are significantly different from each other; WPH subscripts are in cursive. " Significant difference between PLA and WPH at each respective timepoint

during 90ss for both treatments (Fig. 2e; $P>0.05$ ) but were increased for both treatments during BR $(P<0.001)$. There tended to be a period $\mathrm{x}$ treatment interaction $(P=0.082)$. Plasma urea rose throughout the experimental day in both treatments (Fig. 2f; $P<0.001$ ) but was higher for WPH (+ $1.0 \mathrm{mmol} / \mathrm{L} ; 95 \% \mathrm{CI}: 0.5,1.6 ; P<0.001)$ than for PLA during 90ss and BR (+ $1.6 \mathrm{mmol} / \mathrm{L} ; P<0.001 ; 95 \% \mathrm{CI}: 1.1,2.2)$. Plasma ammonium concentrations were increased during 90ss $(\mu \mathrm{mol} / \mathrm{L}$ : PLA, $85.8 \pm 21.6$; WPH, $87.7 \pm$ 22.3) for both treatments $(P<0.001)$ and returned to BL $(\mu \mathrm{mol} / \mathrm{L}: \mathrm{PLA}, 44.7 \pm 9.6$; WPH, $44.8 \pm 9.5)$ during BR ( $\mu \mathrm{mol} / \mathrm{L}$ : PLA, $38.8 \pm 7.3$; WPH, $38.6 \pm 4.8)$. Arterial phenylalanine concentration increased during 90ss in both treatments, but more so in WPH than in PLA (Fig. 3a; $P<0.001$ ). Arterial leucine concentrations increased after protein consumption only and stayed elevated into BR (Fig. 3b; $P<0.001$ ). Arterial phenylalanine enrichment had reached a plateau before commencing 90ss. A slight increase was observed immediately after 90ss in WPH (Fig. 4; $P<0.001$ ).

Urinary urea nitrogen excretion was higher $(+147$ $\mathrm{mg} / \mathrm{hr}$; $P=0.03$; 95\% CI: 13, 281) in WPH $(613 \pm 165$ $\mathrm{mg} / \mathrm{hr})$ than in PLA $(466 \pm 93 \mathrm{mg} / \mathrm{hr})$ during the experimental day (Day 2). Urine production was similar in both treatments (mL/h: PLA, $48 \pm 12$; WPH, $51 \pm 12$; $P=0.65)$.

\section{Forearm protein kinetics}

Forearm phenylalanine net balance was negative at baseline (Fig. 5a). During 90ss, a tendency towards increased rates of amino acid uptake by the forearm (Fig. 5b) was observed. This resulted in a neutral net protein balance in both groups. During BR, the rates of amino acid released from the arm increased (Fig. 5c; $P=0.01$ ), yielding a negative net protein balance. During 90ss forearm plasma flow decreased compared to $\mathrm{BL}$ (Fig. 6; $P<0.001$ ) and increased to a level above $\mathrm{BL}$ during BR (Fig. 6; $P<0.001$ ).

\section{Fractional synthetic rate}

Vastus lateralis FSR was increased during 90ss and BR for both treatments (Fig. 7; $P<0.05$ ).

\section{Muscle signalling and gene expression Western blotting}

In WPH, mTOR phosphorylation was increased immediately after 90ss compared with BL (Fig. 8a; + 58\%; 95\% CI: 6, 111; $P=0.01)$ and PLA $(+64 \% ; 95 \% \mathrm{CI}: 6$, $121 ; P=0.017)$. Also, an overall treatment effect was observed for p70S6K (Fig. 8b; $+20 \%$ in WPH; 95\% CI: 9, 31; $P<0.001)$. p53 phosphorylation tended $(P=0.08)$ to be decreased immediately (Fig. 8c; -20 ; 95\% CI: -38 , $-2)$ and $60 \mathrm{~min}(-22 \%$; 95\% CI: $-40,-4)$ after 90ss across treatments. p-eIF4E and p-p38MAPK were not affected by time or treatment (Fig. $8 \mathrm{~d} \&$ e; $P>0.05$ ).

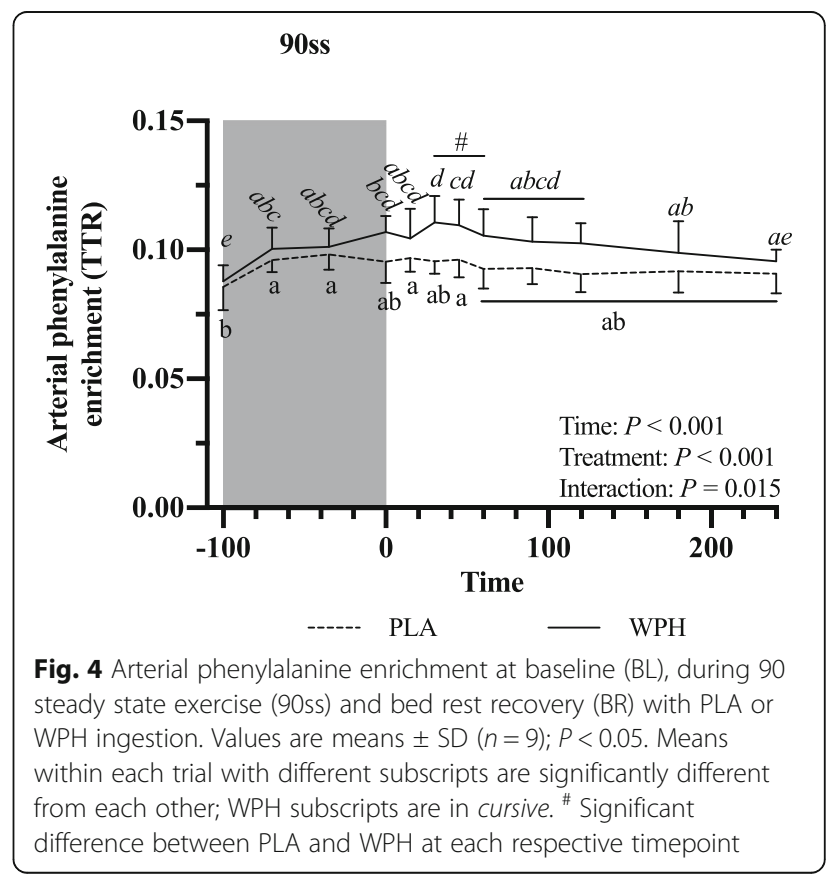




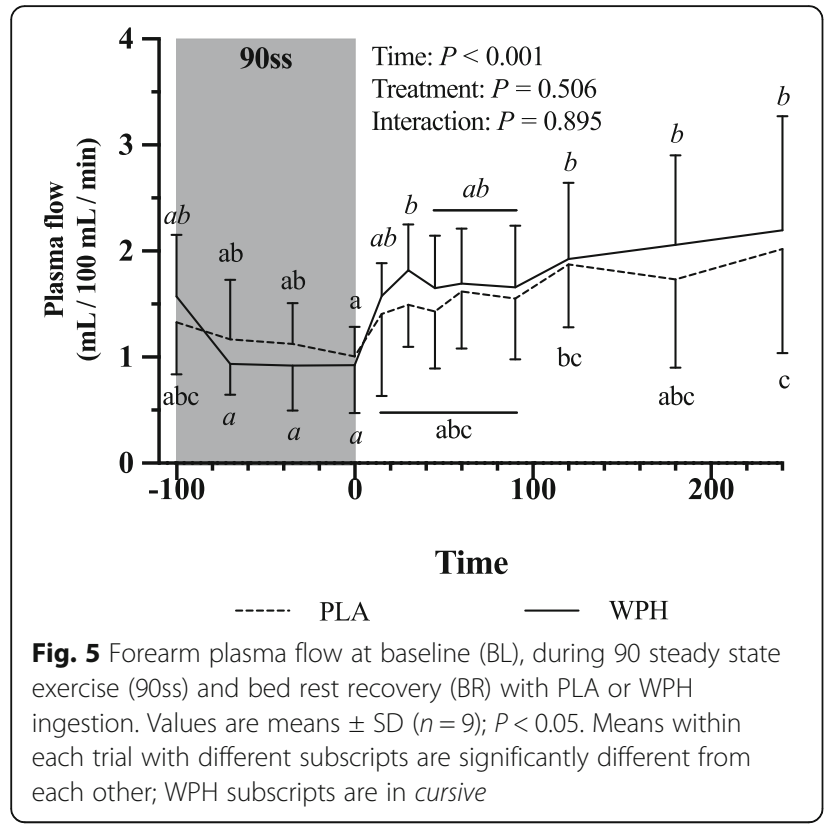

\section{Real-time $P C R$}

In response to 90ss, PGC1 $\alpha$ mRNA expression increased throughout the day to about fivefold at the end of Day 2 (Fig. 9a; $P<0.001$ ). An overall time effect was observed for TFAM mRNA, but post hoc tests revealed no differences from baseline for either treatment (Fig. 9b). $C P T 1 B$ was suppressed immediately after 90ss compared with prior to 90ss (Fig. 9c; $P<0.001$ ) and there tended to be an overall treatment effect indicating a higher expression of CPT1B in the PLA than WPH trial $(P=0.09)$. COX4I1 was not affected by time or treatment (Fig. 9d; $P>0.05$ ).

\section{Discussion}

The main finding of the present study was that supplementation with $\sim 35 \mathrm{~g}$ of protein $(0.5 \mathrm{~g} / \mathrm{kg} \mathrm{LBM})$ did not enhance protein net balance in the forearm or increase vastus lateralis myofibrillar protein synthesis compared to the placebo treatment, despite inducing a rapid increase in plasma amino acid concentrations that lasted into post-exercise recovery. To our knowledge, this is the first study to examine the direct impact of protein ingestion on muscle protein turnover (forearm) and synthesis rates, while training in a state of reduced carbohydrate availability. We used stable isotope tracers to determine protein turnover in the non-exercising muscles (forearm) and fractional protein synthesis in the exercising vastus lateralis muscles during and after bicycle exercise.

Other investigators have hypothesized that protein feeding would mitigate the reputed increase in muscle protein breakdown during exercise by providing substrate for gluconeogenesis and oxidation. A further suggested benefit was that the ingested protein would enhance the muscle protein synthesis rate when training with low exogenous and endogenous carbohydrate availability (training low) [20, 35]. Furthermore, previous reports suggest that the enhanced adaptive response induced by training low is not hampered by a preceding and/or concomitant protein intake [20, 21]. Indeed, protein ingestion during and/or after endurance type exercise has been shown to enhance muscle protein synthesis [33, 34, 36, 37]. However, our data endorse the notion that endurance exercise blunts the anabolic response to hyperaminoacidemia [33, 37], possibly as a part of a metabolic priority shift towards

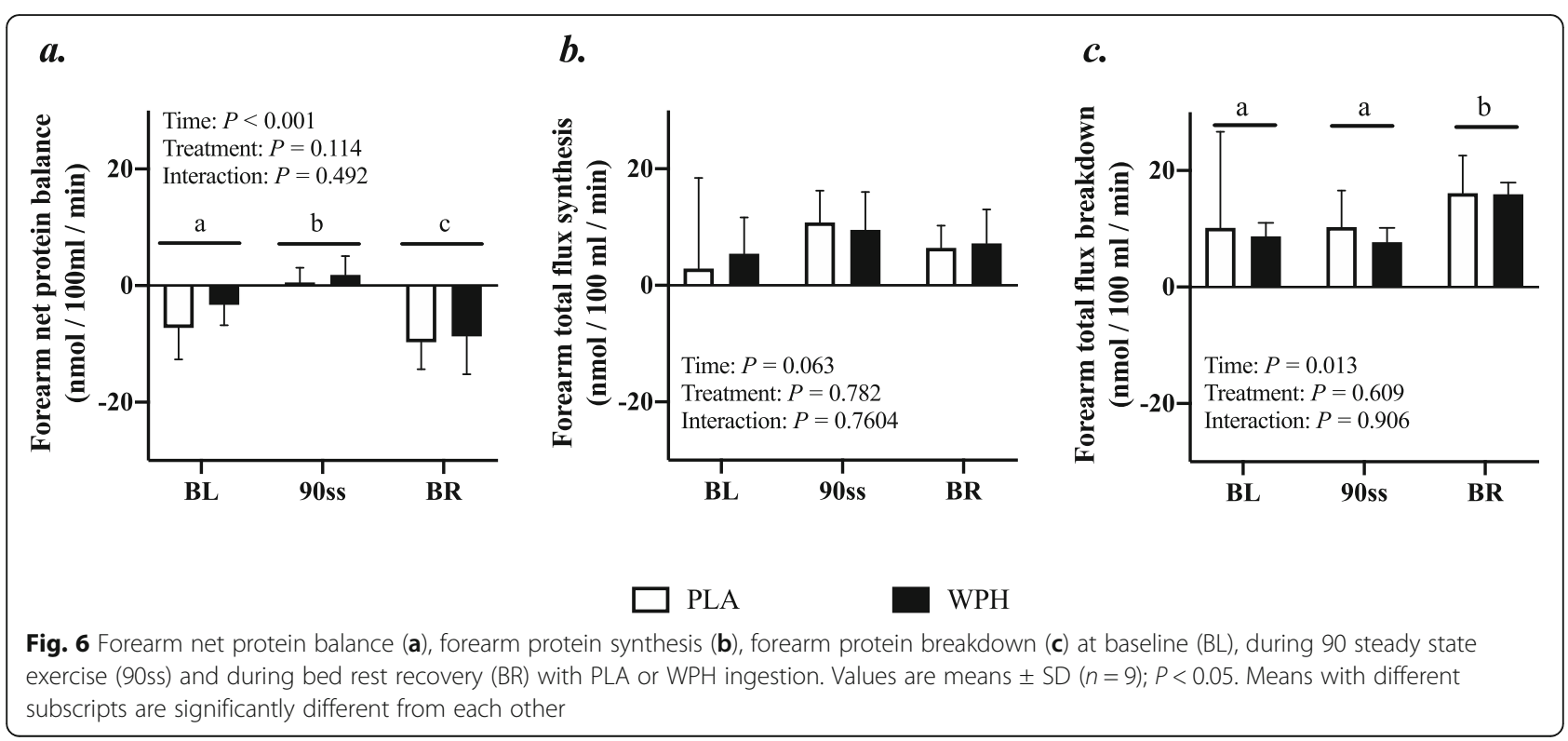




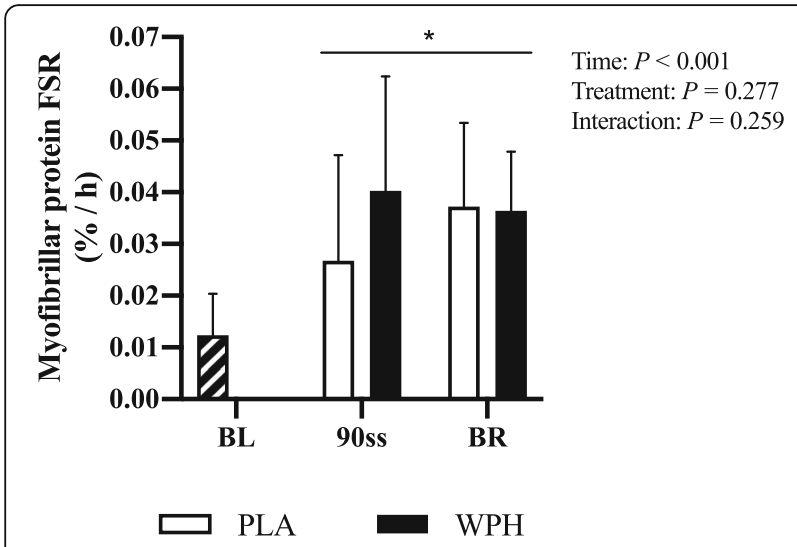

Fig. 7 Muscle protein FSR of the $m$. vastus lateralis during baseline $(\mathrm{BL}), 90 \mathrm{~min}$ steady state exercise (90ss) and bed rest recovery (BR) with PLA or WPH ingestion. BL FSR's were performed at Visit 1 regardless of treatment (hatched bars). Values are means $\pm \mathrm{SD}(n=$ 9); $P<0.05$. * Significantly different from $B L$

energy transduction and conservation as proposed by Atherton and Rennie [38].

\section{Amino acid kinetics and muscle protein synthesis}

We observed that vastus lateralis muscle protein synthesis rates were elevated during and after exercise in both the PLA and the WPH trial. Thus, our data confirm the findings of Beelen et al., who also showed an increase in muscle FSR in response to endurance type exercise with and without exogenous protein provision [37]. Based on observed increases in muscle free amino acid concentrations, Beelen and colleagues suggested that the muscle FSR increase may be attributed to an increased provision of endogenously derived amino acids to the working muscle facilitated by increased blood flow. While this seems a plausible explanation, our tracer kinetics data from the forearm does not suggest that less active muscle tissue becomes a supplier of such amino acids given our results show an increased net protein balance from BL to 90ss in both the WPH and PLA trials. Other studies examining combined protein and carbohydrate ingestion during moderately intense endurance exercise have shown enhanced wholebody [34, 37, 39] and leg [33] protein synthesis and net protein balance compared with carbohydrate or nonfed controls. While the inconsistency between these findings and ours may be influenced by the tissue examined, the lack of carbohydrate and/or energy availability in our subjects likely attenuated the anabolic response to hyperaminoacidemia. Furthermore, we cannot dismiss that the provision of exogenous amino acids via the WPH drink may have ameliorated the muscle protein breakdown in the legs, as observed by Hulston et al. (2011) albeit in subjects who were not reduced in muscle glycogen.
Although we did not measure muscle glycogen content directly, we believe that the HIIT session had lowered the muscle glycogen content significantly. Indeed, similar depletion protocols have been shown to reduce muscle glycogen $\sim 50 \%[7,23]$. Furthermore, these studies show that the achieved reductions in muscle glycogen persisted until the following morning $[7,17,40]$.

\section{Blood parameters}

In accordance with our tracer kinetics data, showing no effect of protein ingestion, plasma metabolite concentrations indicate that the ingested protein bolus was metabolized rather than used as substrate for protein synthesis in the muscle tissues. Had we had access to intrinsically labelled protein, we could have traced the fate of the ingested amino acids. However, the observations of elevated plasma urea in WPH vs PLA (90ss: + 17\%; BR: + $24 \%)$, accompanied by a borderline time $\mathrm{x}$ treatment interaction for plasma glucose levels, imply that amino acids were used as an energy substrate. Moreover, the WPH treatment yielded an overall lower level of cortisol, suggesting that the more stable blood glucose and larger energy substrate provision rendered the subjects less stressed and possibly less catabolic.

The WPH produced an increase in serum insulin concentration compared with the PLA trial. Even though the plasma insulin levels did not rise above rest levels, the slightly higher insulin levels observed in WPH during 90ss may have borne clinical relevance in suppressing lipolysis [41]. Previous studies have shown that insulin repression during exercise is crucial for FFA mobilization and that failure to suppress insulin during exercise blunts plasma FFA markedly [42, 43]. Accordingly, we observed depressed levels of FFA following exercise in WPH compared to PLA.

\section{Myocellular signaling and mRNA-transcription}

Despite WPH being ineffective in augmenting protein synthesis above the PLA trial, WPH elevated phosphorylation in some of the signaling targets involved in translational control of protein synthesis. p-mTOR and p-p70S6K (but not p-eIF4E) showed an elevated relative abundance both immediately and $60 \mathrm{~min}$ after completion of 90ss. This confirms the trend shown by Taylor et al., suggesting an enhanced activity of key regulators of protein synthesis during carbohydrate-restricted exercise if a protein feeding stimulus is provided [20]. Still, from our tracer kinetics data it appears that the energy costly process of translation may be relegated. Thus, WPH seems to have induced a more anabolic environment; but the stimulus was not translated into a detectable alteration of the protein synthesis rate. Furthermore, signaling kinases reputed to be key regulators of mitochondrial biogenesis, i.e. p53 and p38MAPK, 
a.
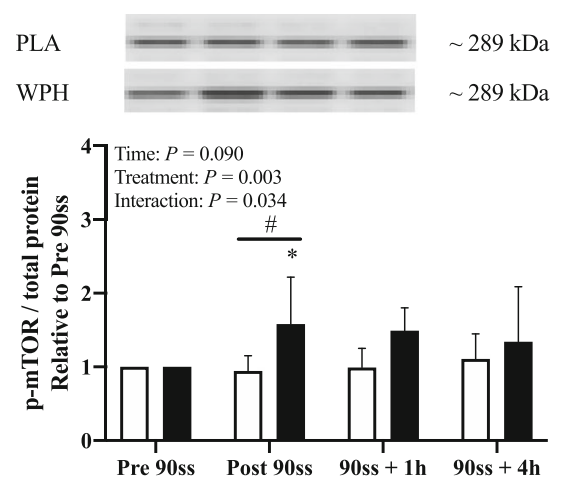

c.
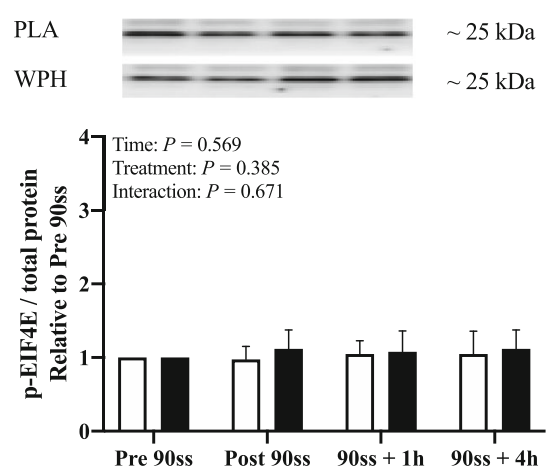

e.
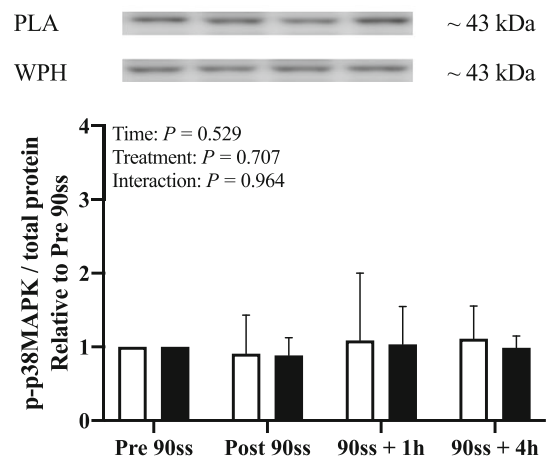

PLA b.

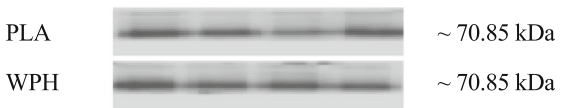

${ }^{4} 7$ Time: $P=0.559$

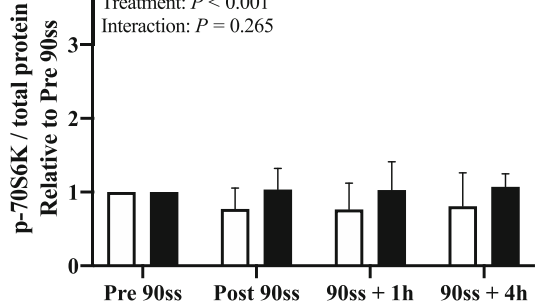

d.
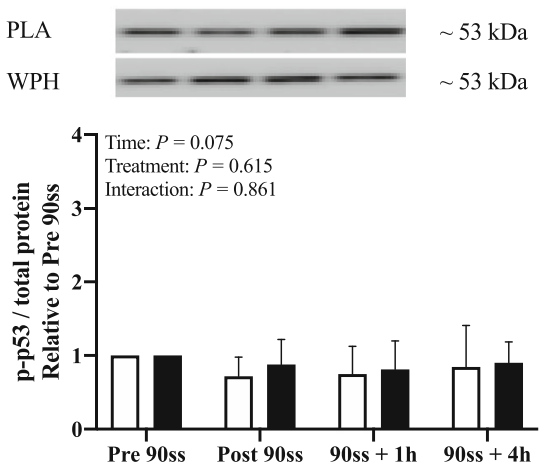

Fig. 8 Protein phosphorylation. Mammalian target of rapamycin (mTOR) (a), ribosomal protein S6 kinase beta-1 (p70S6K) (b), eukaryotic translation initiation factor 4E (EIF4E) (c), tumor protein p53 (p53) (d), p38 mitogen-activated protein kinases (p38MAPK) (e). Western blots representing the time-course effects are presented below the graphs. Based on the applied molecular standards, approximated molecular weights are indicated to the right. $n=9$ for all timepoints. Values are normalized to PRE 90ss and are expressed as means $\pm S D ; P<0.05$. * Significantly different from BL. \# Significant difference between trials

were unaffected by treatment. The observed development for p-p53 and p-p38MAPK must be interpreted on the basis of the previous evening's HIIT session and subsequent overnight fast. Presumably, the phosphorylation of these targets was likely already augmented at the time the baseline biopsy. Thus, comparing these 
a.

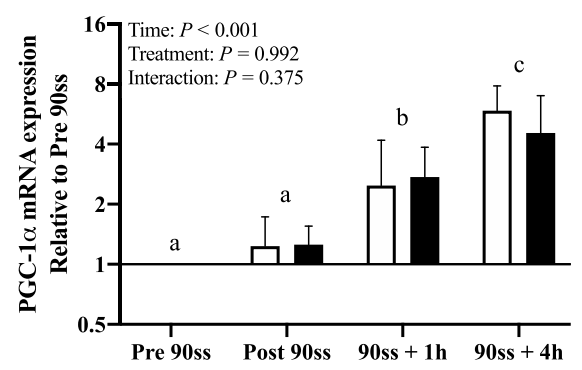

c.

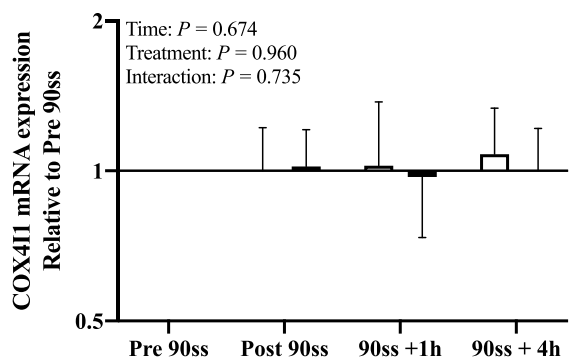

b.

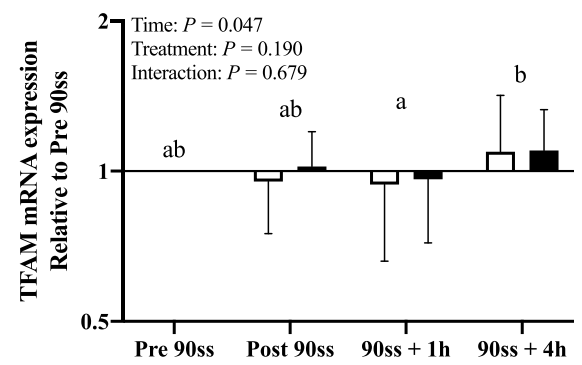

d.

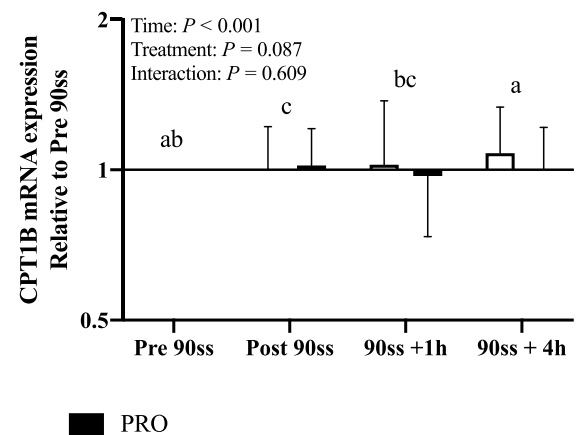

Fig. 9 Gene expression. mRNA expression of peroxisome proliferator-activated receptor gamma coactivator 1-alpha (PGC-1a) (a), mRNA expression of mitochondrial transcription factor A (TFAM) (b), mRNA expression of cytochrome c oxidase subunit IV (COXIM) (c), mRNA expression of carnitine palmitoyl transferase 1B (CPT1B) (d). $n=9$ for all timepoints. Values are set relative to PRE 90ss and the fold changes are expressed as means $\pm S D ; P<0.05$. Means within each trial with different subscripts are significantly different from each other. \# Significant difference between trials

results to the growing body of literature showing increases in p53 and p38MAPK phosphorylation as an effect of a single bout of exercise commenced with reduced muscle glycogen availability (for review see Hawley and Morton [3]) would be inappropriate and, indeed, falls beyond the scope of the present study. While the phosphorylation of p53 and p38MAPK was more or less unaffected by exercise, PGC- $1 \alpha$ mRNA expression was elevated in both trials. This suggests that signaling cascades preceding transcription of genes encoding proteins involved in mitochondrial biogenesis were activated in response to exercise, and that this positive adaptive response did not appear to be negatively affected by protein feeding prior to exercise.

\section{Limitations}

To isolate the effect of the protein ingestion prior to carbohydrate restricted training, we chose a proof-ofprinciple approach. We acknowledge that the omission of post-exercise food intake does not directly translate to a real-world setting. Yet, this approach allowed us gain an understanding of the influence of this particular feeding strategy both during and after training. Furthermore, the addition of post-exercise feeding would have posed even greater methodological challenges in regard to the stable isotope tracer techniques. As we measured the fractional synthesis rate only, we were unable to assess the direct effect of WPH on muscle protein breakdown in the working muscle and evaluate the impact on muscle protein net balance, which may have been affected by protein ingestion per se and by the higher level of insulin in WPH compared to PLA.

Measuring protein turnover during feeding and exercise prompts some methodological challenges arising from physiological perturbations. We used plasma tracer enrichments as a surrogate precursor estimate. Under resting conditions, circulating tracer enrichments, are higher than the intramuscular enrichments [24] and the transfer-RNA precursor enrichment $[44,45]$. This results in an underestimated FSR. During and immediately after exercise, however, the intramuscular tracer enrichment is approaching the level in the circulation [46], resulting in a slighter overestimation of the real precursor enrichment, hence a reduced underestimation of the FSR. We argue that with the use of precursor estimates in the present study, the FSR at basal and in recovery condition 
is more underestimated than during exercise. If anything, the difference in FSR during exercise (90ss) compared to the basal and recovery condition is smaller than what we report. Conservatively, we suggest that our quantitative measures should be interpreted as indicative. Still, we find that our collective portfolio of outcomes supports our tracer kinetics data and forms a basis from which a valid conclusion may be drawn. Furthermore, our sample size was small which may have reduced our ability to detect statistical effects for muscle protein turnover. Additionally, it is worth noting, that the participants in the present trial were all men. This potentially limits broader inferences of our findings, i.e. to the female athletic population. Finally, our participants were trained, but not all part of the international elite of endurance athletes. We cannot rule out that training status influence protein turnover at the response to protein supplements.

\section{Summary}

In summary, we provide novel data showing that protein ingested prior to endurance-type exercise in the energyand carbohydrate-restricted state does not enhance myofibrillar FSR in the working muscles or improve muscle protein balance in the non-working muscles compared to ingestion of non-caloric control. Presumably, this observation is linked to a metabolic priority shift towards energy preservation. During exercise, we observed slight augmentations in muscle protein synthesis rates in the exercising muscles and net balance in the non-exercising muscles, independently of protein feeding. This suggests that the practice of commencing training in a glycogendepleted/fasted condition to enhance endurance-training adaptations does not appear to pose any significant risk in regard to losing skeletal muscle mass. However, protein breakdown is upregulated following exercise, at least in non-exercising muscles, thus sufficient refueling in terms of protein and carbohydrate is crucial to induce an anabolic hormone response, stimulate glycogen resynthesis and protein synthesis, as well as attenuate protein breakdown.

\section{Supplementary information}

Supplementary information accompanies this paper at https://doi.org/10. 1186/s12970-020-0338-z.

Additional file 1. Amino acid profile. Beverage amino acid profile and peptide distribution.

Additional file 2. Calculations. Tracer kinetics calculations.

\section{Abbreviations}

90ss: 90 min steady state cycling; AMPK: AMP-activated kinase; BL: Baseline; BR: Bed rest; COX411: Cytochrome c oxidase subunit 4 isoform 1; CPT1B: Carnitine palmitoyltransferase I b; DXA: Dual-energy x-ray absorptiometry; eEF2: Eukaryote elongation factor 2; FFA: Free fatty acid; FSR: Fractional synthesis rates; h: Hour/hours; HIIT: High-intensity interval training; LBM: : Lean body mass; mTOR: Mammalian target of rapamycin; pelF4E: Phospho-Eukaryotic translation initiation factor 4E; PGC-1a: Peroxisome proliferator-activated receptor gamma coactivator -1a; PLA: Placebo; pp38MAPK: Phospho-p38 mitogen-activated protein kinases; p-p53: Phosphop53; p-p70S6K: Phospho-p70S6 kinase; PPO: Peak power output; RPLPO: 60S acidic ribosomal protein PO; SD: Standard deviation; TFAM: Mitochondrial transcription factor A; WPH: Whey protein hydrolysate

\section{Acknowledgements}

The authors are thankful for the volunteers who enthusiastically participated in this study. The authors would also like to thank Mie B. Olesen, Gitte K. Hartvigsen, Janni M. Jensen, Hanne Petersen, Annette Mengel, Lone Kvist and Ermina Bach for their assistance and advice.

\section{Authors' contributions}

Study design: MSL, URM, LH, MHV, NM and MH. Subject recruitment, screening and physical tests: MSL. Conducting the experimental days: MSL, OLD, MBB, AH and MVS. Stable isotope analyses: MSL, LH and GVH. PCR analyses: LBD. Interpretation of data MSL, LH, URM and MH are responsible for the analyses and interpretation of all data. Drafted the manuscript: MSL. Critical revision: MH, URM, LH, NM, MBB, AJH, MVS, OLD, MHV, LBD and GVH. All authors read and approved the final manuscript.

\section{Funding}

The study was funded by research grants from Arla Foods Ingredients Group P/S, Team Denmark, Toyota-Fonden Denmark, Innovation Fund Denmark (grant 5016-00118B) and The Ministry of Culture Denmark (FPK. 2015-0038).

\section{Availability of data and materials}

The datasets used and/or analyzed during the current study are available from the corresponding author on reasonable request.

\section{Ethics approval and consent to participate}

All participants were given oral and written information and gave their written consent to participate. The study was approved by the local ethical committee of the Central Denmark Region (M-20110035) and was conducted in accordance with the Declaration of Helsinki. The study was registered with clinicaltrials.gov (NCT01320449).

\section{Consent for publication}

Not applicable.

\section{Competing interests}

The study was funded in part by a research grants from Arla Foods Ingredients Group P/S. MSL and URM currently hold positions at Arla Foods Ingredients $\mathrm{P} / \mathrm{S}$ as industrial PhD-student and research scientist, respectively. The views expressed in the manuscript are those of the authors and do not necessarily reflect the position or policy of Arla Foods Ingredients P/S, Denmark. The other authors have no conflict of interest.

\section{Author details}

'Department of Public Health, Aarhus University, Dalgas Ave. 4, 8000 Aarhus C, Denmark. ${ }^{2}$ Arla Foods Ingredients Group P/S, Viby J 8260, Denmark. ${ }^{3}$ School of Sport, Exercise and Rehabilitation Sciences, University of Birmingham, Birmingham, UK. ${ }^{4}$ Medical Research Laboratory, Institute for Clinical Medicine, Aarhus University, Aarhus C, Denmark. ${ }^{5}$ Department of Endocrinology, Aarhus University Hospital, Aarhus N, Denmark. ${ }^{6}$ Department of Biomedicine, Aarhus University, Aarhus C, Denmark. 'Department of Nuclear Medicine and PET-Centre, Aarhus University Hospital, Aarhus N, Denmark. ${ }^{8}$ Clinical Metabolomics Core Facility, Clinical Biochemistry, Rigshospitalet, Copenhagen, Denmark. ${ }^{9}$ Department of Biomedical Sciences, Faculty of Health and Medical Sciences, University of Copenhagen,

Copenhagen, Denmark.

Received: 19 August 2019 Accepted: 14 January 2020

Published online: 28 January 2020

\section{References}

1. Jeukendrup AE. Periodized nutrition for athletes. Sports Med. 2017;47:51-63.

2. Close GL, Hamilton DL, Philp A, et al. New strategies in sport nutrition to increase exercise performance. Free Radic Biol Med. 2016;98:144-58. 
3. Hawley JA, Morton JP. Ramping up the signal: promoting endurance training adaptation in skeletal muscle by nutritional manipulation. Clin Exp Pharmacol Physiol. 2014;41:608-13.

4. Burke LM. Fueling strategies to optimize performance: training high or training low? Scand J Med Sci Sports. 2010;20(Suppl 2):48-58.

5. Hansen AK, Fischer CP, Plomgaard $P$, et al. Skeletal muscle adaptation: training twice every second day vs. training once daily. J Appl Physiol (1985). 2005:98:93-9.

6. Van Proeyen K, Szlufcik K, Nielens H, et al. Beneficial metabolic adaptations due to endurance exercise training in the fasted state. J Appl Physiol (1985). 2011;110:236-45.

7. Lane SC, Camera DM, Lassiter DG, et al. Effects of sleeping with reduced carbohydrate availability on acute training responses. J Appl Physiol (1985) 2015;119:643-55

8. Bartlett JD, Louhelainen J, labal Z, et al. Reduced carbohydrate availability enhances exercise-induced p53 signaling in human skeletal muscle: implications for mitochondrial biogenesis. Am J Physiol Regul Integr Comp Physiol. 2013;304:R450-8

9. Yeo WK, Paton CD, Garnham AP, et al. Skeletal muscle adaptation and performance responses to once a day versus twice every second day endurance training regimens. J Appl Physiol (1985). 2008:105:1462-70.

10. Hulston CJ, Venables MC, Mann CH, et al. Training with low muscle glycogen enhances fat metabolism in well-trained cyclists. Med Sci Sports Exerc. 2010:42:2046-55

11. Morton JP, Robertson C, Sutton L, et al. Making the weight: a case study from professional boxing. Int J Sport Nutr Exerc Metab. 2010;20:80-5.

12. Walsh D. Inside team sky. United Kingdom: Simon \& Schuster UK Ltd; 2013. p. 352.

13. Mitchell N, Cook N. Fuelling the cycling revolution: the nutritional strategies and recipes behind grand tour wins and olympic gold medals. London: Bloomsbury Publishing Plc; 2017. (Series Editor)

14. Tarnopolsky M. Protein requirements for endurance athletes. Nutrition. 2004 20:662-8 (Burbank, Los Angeles County, Calif).

15. Lemon PW, Mullin JP. Effect of initial muscle glycogen levels on protein catabolism during exercise. J Appl Physiol Respir Environ Exerc Physiol. 1980:48:624-9.

16. Howarth KR, Phillips SM, MacDonald MJ, et al. Effect of glycogen availability on human skeletal muscle protein turnover during exercise and recovery. J Appl Physiol (1985). 2010;109:431-8.

17. Van Hall G, Saltin B, Wagenmakers AJ. Muscle protein degradation and amino acid metabolism during prolonged knee-extensor exercise in humans. Clin Sci (Lond). 1999;97:557-67.

18. Mettler S, Mitchell N, Tipton KD. Increased protein intake reduces lean body mass loss during weight loss in athletes. Med Sci Sports Exerc. 2010;42:326-37.

19. Margolis LM, Pasiakos SM. Optimizing intramuscular adaptations to aerobic exercise: Effects of carbohydrate restriction and protein supplementation on mitochondrial biogenesis. Adv Nutr (Bethesda, Md). 2013;4:657-64

20. Taylor C, Bartlett JD, van de Graaf CS, et al. Protein ingestion does not impair exercise-induced ampk signalling when in a glycogen-depleted state: implications for train-low compete-high. Eur J Appl Physiol. 2013; 113:1457-68.

21. Impey SG, Smith D, Robinson AL, et al. Leucine-enriched protein feeding does not impair exercise-induced free fatty acid availability and lipid oxidation: beneficial implications for training in carbohydrate-restricted states. Amino Acids. 2015:47:407-16.

22. Hawley JA, Noakes TD. Peak power output predicts maximal oxygen uptake and performance time in trained cyclists. Eur J Appl Physiol Occup Physiol. 1992;65:79-83

23. Stepto NK, Martin DT, Fallon KE, et al. Metabolic demands of intense aerobic interval training in competitive cyclists. Med Sci Sports Exerc. 2001;33:303-10.

24. Holm L, Reitelseder S, Dideriksen K, et al. The single-biopsy approach in determining protein synthesis in human slow-turning-over tissue: use of flood-primed, continuous infusion of amino acid tracers. Am J Phys Endocrinol Metab. 2014:306:E1330-9.

25. Rittig N, Bach E, Thomsen $\mathrm{HH}$, et al. Amino acid supplementation is anabolic during the acute phase of endotoxin-induced inflammation: A human randomized crossover trial. Clin Nutr (Edinburgh, Scotland). 2016;35:322-30.

26. Christensen B, Nellemann B, Larsen MS, et al. Whole body metabolic effects of prolonged endurance training in combination with erythropoietin treatment in humans: a randomized placebo controlled trial. Am J Phys Endocrinol Metab. 2013;305:E879-89.
27. Burd NA, Groen BB, Beelen M, et al. The reliability of using the single-biopsy approach to assess basal muscle protein synthesis rates in vivo in humans. Metab Clin Exp. 2012;61:931-6.

28. Burd NA, West DW, Rerecich $T$, et al. Validation of a single biopsy approach and bolus protein feeding to determine myofibrillar protein synthesis in stable isotope tracer studies in humans. Nutr Metab. 2011:8:15.

29. Rooyackers OE, Adey DB, Ades PA, et al. Effect of age on in vivo rates of mitochondrial protein synthesis in human skeletal muscle. Proc Natl Acad Sci U S A. 1996:93:15364-9.

30. Bechshoeft R, Dideriksen KJ, Reitelseder S, et al. The anabolic potential of dietary protein intake on skeletal muscle is prolonged by prior light-load exercise. Clin Nutr (Edinburgh, Scotland). 2013;32:236-44

31. Smith Gl, Patterson BW, Klein SJ, et al. Effect of hyperinsulinaemiahyperaminoacidaemia on leg muscle protein synthesis and breakdown: reassessment of the two-pool arterio-venous balance model. J Physiol. 2015; 593:4245-57.

32. Pfaffl MW. A new mathematical model for relative quantification in real-time rt-pcr. Nucleic Acids Res. 2001;29:e45

33. Hulston CJ, Wolsk E, Grondahl TS, et al. Protein intake does not increase vastus lateralis muscle protein synthesis during cycling. Med Sci Sports Exerc. 2011;43:1635-42.

34. Koopman $\mathrm{R}$, Pannemans $\mathrm{DL}$, Jeukendrup $\mathrm{AE}$, et al. Combined ingestion of protein and carbohydrate improves protein balance during ultra-endurance exercise. Am J Phys Endocrinol Metab. 2004:287:E712-20.

35. Impey SG, Hearris MA, Hammond KM, et al. Fuel for the work required: a theoretical framework for carbohydrate periodization and the glycogen threshold hypothesis. Sports Med. 2018;48:1031-48.

36. Howarth KR, Moreau NA, Phillips SM, et al. Coingestion of protein with carbohydrate during recovery from endurance exercise stimulates skeletal muscle protein synthesis in humans. J Appl Physiol (1985). 2009;106:1394-402.

37. Beelen M, Zorenc A, Pennings $B$, et al. Impact of protein coingestion on muscle protein synthesis during continuous endurance type exercise. Am J Phys Endocrinol Metab. 2011:300:E945-54.

38. Atherton PJ, Rennie MJ. Protein synthesis a low priority for exercising muscle. J Physiol. 2006:573:288-9.

39. Beelen M, Tieland M, Gijsen AP, et al. Coingestion of carbohydrate and protein hydrolysate stimulates muscle protein synthesis during exercise in young men, with no further increase during subsequent overnight recovery. Nutr. 2008;138:2198-204.

40. Maehlum S, Hermansen L. Muscle glycogen concentration during recovery after prolonged severe exercise in fasting subjects. Scand J Clin Lab Invest. 1978:38:557-60.

41. Jensen MD, Caruso M, Heiling V, et al. Insulin regulation of lipolysis in nondiabetic and iddm subjects. Diabetes. 1989:38:1595-601.

42. Wasserman DH, Lacy DB, Goldstein RE, et al. Exercise-induced fall in insulin and increase in fat metabolism during prolonged muscular work. Diabetes. 1989;38:484-90

43. Marker JC, Hirsch IB, Smith $\sqcup$, et al. Catecholamines in prevention of hypoglycemia during exercise in humans. Am J Phys. 1991;260:E705-12.

44. Toffolo G, Albright $R$, Joyner $M$, et al. Model to assess muscle protein turnover: domain of validity using amino acyl-trna vs. surrogate measures of precursor pool. Am J Phys Endocrinol Metab. 2003;285:E1142-9.

45. Chow LS, Albright RC, Bigelow ML, et al. Mechanism of insulin's anabolic effect on muscle: measurements of muscle protein synthesis and breakdown using aminoacyl-trna and other surrogate measures. Am J Phys Endocrinol Metab. 2006;291:E729-36.

46. Reitelseder S, Dideriksen K, Agergaard J, et al. Even effect of milk protein and carbohydrate intake but no further effect of heavy resistance exercise on myofibrillar protein synthesis in older men. Eur J Nutr. 2019:58(2):583-95.

\section{Publisher's Note}

Springer Nature remains neutral with regard to jurisdictional claims in published maps and institutional affiliations. 